\title{
Reconciling specific and unspecific risk factors: the interplay between theory and data
}

\author{
Jan K. Buitelaar
}

Received: 4 May 2010/Accepted: 6 May 2010/Published online: 22 May 2010

(c) The Author(s) 2010. This article is published with open access at Springerlink.com

From this issue onwards, one of the editors will introduce the published set of papers by an editorial. This may serve to both highlight some papers as well as to provide a personal touch to a relevant topic of child and adolescent psychiatry.

A basic premise of our understanding of the origins of child and adolescent psychopathology is that both genes and the environment are crucially and equally important. Put into a simple formula: the effect of genes $=100 \%$ and the effect of the environment $=100 \%$. No developing organism without genes, but neither one without environmental influences, structure and context. The challenge of research is to unravel the complicated interplay between genetic and environmental risk factors in shaping development and translate this understanding to clinically relevant approaches to intervention and prevention. A key finding has been that variation in the promoter region of the human serotonin transporter gene influences the sensitivity to stressful life events and having been exposed to childhood maltreatment. Those carrying the short allel have increased risk for depression and suicidal thought following exposure to stressful life events and childhood maltreatment [1]. This landmark paper led to a long series of attempts to replicate, and many did successfully. Recent meta-analyses, however, took a critical stance, questioning what would constitute a real replication of such a gene by environment interaction finding [3, 4]. These meta-analyses, in turn, appeared to have missed the broader biological

\footnotetext{
J. K. Buitelaar $(\square)$

Donders Institute of Brain, Cognition and Behavior,

Karakter Child and Adolescent Psychiatry University Cluster, P.O. Box 9101 (Internal Post 204), 6500 HB Nijmegen,

The Netherlands

e-mail: j.buitelaar@psy.umcn.nl
}

theory and well-established neuroscience foundation for this interaction effect [2] and to have taken a selective sample of studies for review [5].

One element of this discussion is how specific the risk factors, be it in the gene or the environment, should be defined and whether the more specific is always the better. Getting it as specific as possible clearly may detract from the possibility to generalise the findings to a broader theory of functioning. The paper by Floury et al. in this issue bears on this topic and shows that a cumulative, thus more general or unspecific, measure of environmental risk factors provides the strongest account of psychopathology in a large sample of 3-year-old children in the UK. At the same time, however, the authors demonstrate that the effects of environmental adversity are moderated by very specific protective factors. Non-verbal ability moderated the effect of proximal family risk on conduct and emotional problems, and developmental milestones moderated the effect of proximal family risk on conduct problems. The lesson to be learned is that it is the interplay between theory (in this case that the protective factors would be located in the children's cognitive domain) and data that will provide the most useful answers in this discussion.

The paper by van Oort et al. adds another perspective by examining whether anxiety and depression, which are so often co-occurring, have similar or different correlates in the family environment. Van Oort et al. show that there are differential associations between risk factors from the family environment and anxiety and depression in adolescents. Family dysfunction appears to be more strongly associated with anxiety than with depression, whereas parenting stress is more strongly associated with depression.

Finally, Noterdaeme et al. focus on the issue of how specific and distinct our diagnostic categories should be. In 
a follow-up study of a well-characterized sample of subjects with Asperger syndrome and high-functioning autism, the distinctions between the two groups of subjects at about 10 years of age in terms of psychopathology, cognition and level of functioning were minor. The differences in verbalIQ and language skills between the two groups were not surprising and could be explained through the definition of the syndromes. This questions the validity of the diagnostic distinction between Asperger syndrome and high-functioning autism within the category of autism spectrum disorders and links with the recent proposals for the revised DSM classification (http://www.dsm5.org).

Open Access This article is distributed under the terms of the Creative Commons Attribution Noncommercial License which permits any noncommercial use, distribution, and reproduction in any medium, provided the original author(s) and source are credited.

\section{References}

1. Caspi A, Sugden K, Moffitt TE, Taylor A, Craig IW, Harrington H, McClay J, Mill J, Martin J, Braithwaite A, Poulton R (2003) Influence of life stress on depression: moderation by a polymorphism in the 5-HTT gene. Science 301(5631):386-389

2. Caspi A, Hariri AR, Holmes A, Uher R, Moffitt TE (2010) Genetic sensitivity to the environment: the case of the serotonin transporter gene and its implications for studying complex diseases and traits. Am J Psychiatry 167: 509-527

3. Munafo MR, Brown SM, Hariri AR (2008) Serotonin transporter (5-HTTLPR) genotype and amygdala activation: a meta-analysis. Biol Psychiatry 63(9):852-857

4. Risch N, Herrell R, Lehner T, Liang KY, Eaves L, Hoh J, Griem A, Kovacs M, Ott J, Merikangas KR (2009) Interaction between the serotonin transporter gene (5-HTTLPR), stressful life events, and risk of depression: a meta-analysis. JAMA 301(23):2462-2471

5. Rutter M (2010) Gene-environment interplay. Depress Anxiety 27(1):1-4 